\title{
Conceptual considerations for studying churches' engagement with urban fractures and vulnerabilities
}

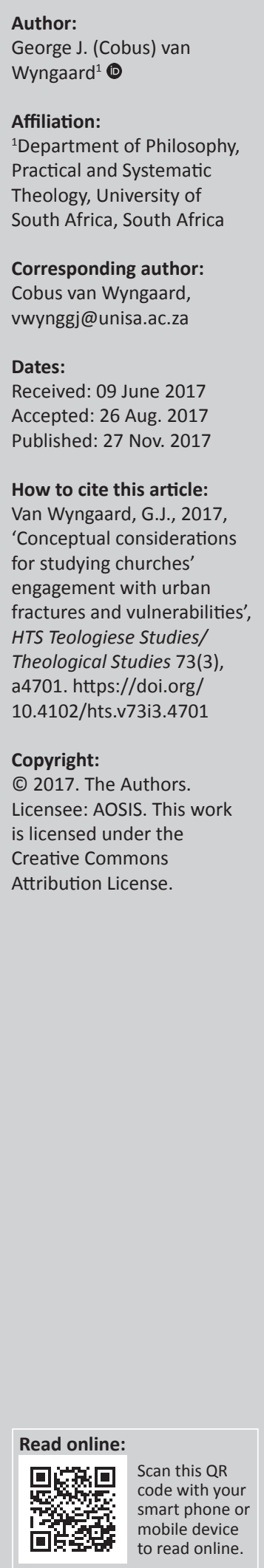

This article provides an overview of conceptual considerations underpinning the design of a research project on religious innovation and competition amidst urban social change. The conceptual work developed out of the planning of the research methods, questions and questionnaires, and provides the background on which particular methodological choices and research foci were built. In six sections, the following will be discussed: the tension between a liberation theology commitment and ethnographic description of local congregations' response to social change; the motivation for a particular understanding of 'church' used in identifying communities for the mapping process and focus groups; assumptions on the relation between church or theology and society; introduction to the key notions 'urban fractures' and 'vulnerabilities' used in the study; and our understanding of 'innovation'.

\section{Introduction}

This article is the first in a series of publications from a research project on religious innovation and competition amidst urban social change, ${ }^{1}$ entitled 'Religious innovation and competition amidst urban social change: a Pretoria case study'. ${ }^{2}$ The research was conducted during 2016 and 2017 in Pretoria Central and Mamelodi East, and focused on exploring how local churches respond to urban change and vulnerability. While other articles will explore the methodology (De Beer, Smith \& Manyaka 2017) and specific themes emerging from the research, ${ }^{3}$ this article will provide an overview of key conceptual considerations underpinning the design of the research project.

The first half of the article will provide a description of our theological position and understanding of church and its relation to social change. The second half will then proceed to discuss the notions of urban fractures, vulnerability and innovation as these relate to this research project. The purpose of the article is to provide clarity on key notions used in conceptualising this research project. However, we took note that these are concepts that are also often drawn into theological research concerned with social change. This article therefore seeks to both contribute towards a clearer understanding of the research method and findings of the project, but also to provide some guideposts for similar and further research on the churches' engagement with urban fractures and vulnerabilities, or with social change more generally.

\section{Black and liberation theologies and the church}

What drew a large part of the research group to this project was in part our commitments to black and liberation theologies, ${ }^{4}$ as well as our interest in the urban context specifically. However, this theological commitment produced a creative tension which we had to engage with repeatedly as we gathered and reflected on the data emerging from the churches the broader research team was working with. This became a key aspect of self-critique, and it impacted on numerous conceptual

1.The author is grateful for the rich engagement from the research group around the concepts discussed below, in particular, to Nico
Botha, and also to Stephan de Beer, Eugene Baron, Jacob Manyaka, Michael Ribbens and Ezekiel Ntakirutimana. References in the
plural below usually refer to this broader research team which repeatedly discussed the issues in this article. That said, the article was
written by myself and they cannot be held responsible for mistakes in the argument below.

2.This project was supported by the Nagel Institute as part of a more comprehensive research initiative under the larger heading 'Christianity and Social Change in Contemporary Africa'.

3.This article forms part of a broader publication which includes the articles mentioned research project from which a number of other publications will be appearing.

4.The reference to black and liberation theologies does not mean to oppose the one to the other. We understood black theology to be a theology of liberation (see Vellem 2012), but also acknowledge that while the research group was informed by South African Black Theology of Liberation in a particular way, it was also the broader family of liberation theologies that informed our reflection.

Note: This article forms part of a collaborative research project entitled 'Religious innovation and competition amidst urban social change: a Pretoria case study'. The project was funded by the Templeton Foundation as part of an African-wide enquiry on 'Christianity and social change in contemporary Africa'.

The project is also a sub-theme of the 'Faith in the City' research project, hosted by the Centre for Contextual Ministry in the Faculty of Theology, University of Pretoria. 
and methodological aspects discussed below and in subsequent articles. This tension is found in the relation between academic theology of liberation and the praxis of the local congregation.

In spite of an explicitly stated commitment to people in general, the poor in particular, and to grassroots communities, much of liberation theology at universities risks taking its academic opponents as key interlocutors, rather than actual people in poor communities. More specifically, as key notions from liberation theology became more widely accepted, liberation theology itself became a middle-class intellectual elite conversation disconnected from local communities (Hankela 2014:3-4). Rothney Tshaka names this as a 'methodological restlessness', where an obsession with method, indeed often primarily because of the ongoing criticisms from its opponents, is partly responsible for the failure of academic theology's (in this case, academic liberation theology's) lack of engagement with the very communities it seeks to empower (Tshaka 2010:126-127, 133-134). This takes us back to the very foundation of liberation theology: who the interlocutor of our theology should be - and the specific challenge of this question for liberation theologies within a post-apartheid South Africa (Vellem 2012). What would it mean to take those whose humanity is systematically denied as key interlocutors for our theology?

This tension between the academy and people, in particular the poor, has at times been met by a repeated emphasis on local faith communities as the place where liberation theology must take root in critical tension with the academic projects situating themselves in the tradition of liberation theology. For example, Elina Hankela's (2014) recent proposal, important for our own project because of its focus on the South African urban context and the explicit engagement of faith communities as place where liberation theology must take root, starts with the premise that the local church, even if not every local congregation, represents all sectors and classes of society, and the liberation theology should work from within this community for a dialogue which is not simply academic, but allow people to speak. In particular, liberation theology should work for the whole community, which imply a specific focus on marginalised and silenced voices.

Starting from the premise that the inner city and township areas of Tshwane (and of many other South African cities) are places within our fractured urban structure where those who are vulnerable reside, and that faith communities within these areas represent the people from these areas, we therefore wanted to give priority to making the voices from these communities, through the faith communities worshipping here, central.

Our own tension was, however, with ourselves as academic theologians, within the context of research funding and university support an identity which was always relevant to our engagements, and our relation to people, in particular local churches. It was exactly our own strong convictions concerning liberation - our analysis of the context and theological commitments to justice, our convictions on the importance of people having agency over their own lives and our critique on charity which maintains inequalities - on the one hand, our convictions that the local faith community in the inner city and township of South Africa need to be given the space to articulate their own analysis of the context and responses to the challenges raised, and that part of our academic posture should include a deep trust of people (Freire 1996:42), in this case of local churches, which gave rise to this tension. The question for us is therefore how we as academic theologians ourselves are in dialogue with people in local faith communities, particularly faith communities in poor and vulnerable communities.

It would have been impossible for us to ignore our personal liberation theology commitments, and indeed this is what drew us towards an emphasis on churches, and in particular small independent churches, churches led by women and churches outside the denominational institutions which we ourselves are mostly from. Simultaneously, we had to constantly take note of the fact that our analysis of the context was at times quite different from that emerging from these faith communities. The sections on the church and the church and social context relation below therefore expand on an understanding of church which allows voices from grassroots faith communities to emerge. ${ }^{6}$ However, our own liberation theology commitments also raise questions concerning the contextual analysis emerging from faith communities and the theological and other responses emerging from faith communities.

Central to this entire project is therefore a commitment to allow people in particular communities to speak to their own problems and articulate their own responses to these realities, while bringing critical perspectives from the academy into concrete dialogue with these perspectives. As research on particular aspects of the urban context - precarious housing, migration, youth agency and so on - is published, this dialogue between our commitments to appreciatively describing what is emerging from the church, assuming that there are valuable (innovative) responses that our own academic context fails to immediately note, while not romanticising the poor church, and critically engaging these responses, will become clear.

\section{Church}

One conscious decision we made early in the project deserves brief mention before proceeding with the discussion. Noting both the majority Christian context of South Africa, and also the limitation within the research team in that we are all from a Christian background, we focused our research on Christian communities of faith. While the importance of asking similar questions to other faith communities was duly noted, we were also aware of the risk of describing the diversity within the Christian faith in a highly nuanced manner, while describing other faith communities through a single example - thus being sensitive to the rich diversity 6.De Beer, Smith and Manyaka (2017) expand on methodological considerations and the process which gave concrete expression to this commitment. 
within Christianity while assuming that a single Mosque could stand in for all of Islam. Gathering sufficient data on other faith communities in a responsible manner will require a broader process than we were able to embark on. Such an interreligious perspective on how South African communities of faith respond to urban fractures and vulnerabilities would be important for further research.

Our focus was explicitly on churches. However, 'church' can be a very ambiguous concept. The word 'church' is used in a variety of different ways, with these different meanings today often associated with different 'forms' that the church may take. On the one hand, it is important that we remain clear on what is meant by church in a particular context, while constantly noting that a focus on one form does not imply reducing 'the church' to this form (Smit 2008:70-71). Explicit consideration had to be given not only to what we mean when we speak about 'church' in this research, but also who is being included or excluded from what we describe as church.

We focused on the local church, in this instance defined as a local worshipping community, or the church assembled (see Volf 1998:135-136). This emphasis on the local church as the primary agent responding to social change, what might be described as the primary agent of mission (Bosch 2004:381), is no longer strange, but it did have specific implications for how and where we focused our research in this instance.

Our focus on the local congregation and worshipping community does not imply that the denomination, organisations of volunteers or individual believers in their lives in this world are not also church, and does not also respond in innovative ways to urban change. However, the emphasis on the local congregation resulted in a conscious decision that the broader church structures (on denominational level or regional level) and the numerous non-governmental organisations (NGOs) and faith-based organisations (FBOs) working in Pretoria Central and Mamelodi East will be excluded from the research, even while many of these would be different forms of church. Furthermore, we acknowledged that worship is not limited to the local congregation, but that some FBOs in the area are also quite intentionally worshipping communities, even while not functioning as congregations. In these instances where worship was found within an organisation which explicitly defined itself as not being a local congregation, we excluded these from the data as well.

While we were familiar with many of these organisations, and therefore easily excluded them from the beginning, this conscious focus also assisted us during the process to determine where data will be collected. As an example, in one instance, a large inner-city Pentecostal church responded to our request for doing a focus group with leaders and members by indicating that the work the church does on matters we were interested in, does not reside with the local congregation but is organised from the 'head office'. We were therefore instructed to contact the head office, which was situated in a suburban area far from the inner city, for a focus group on how the church responds to urban change and vulnerabilities. Our decision was to refrain from including such a focus group in our research, because this would fall outside the form of church that we were focusing on - again, our interest was on how the community assembling for worship in the inner city responded to these realities.

However, this commitment to the local church still left us with questions on who is included. By focusing on the church assembled, we set as criteria that church in this instance refers to those who gather for public worship. 'Finding' and mapping churches most often literally meant walking the streets on a Sunday morning and seeing where people are gathering for worship, or asking people on the streets where local churches are. But beyond this, we set no criteria. While theologically some marks would always be given for what constitutes the church (sacraments, confession, office, etc.), we consciously refrained from using any further criteria beyond the focus on those who gather for public worship. The result was a far more diverse set of churches than we ourselves imagined to find. Currently, we are aware of 54 churches in an approximately $4 \mathrm{~km}^{2}$ area in Pretoria Central, and 33 churches in an approximately $6 \mathrm{~km}^{2}$ area in Mamelodi East. What we worked with can therefore be described as a common-sense understanding of church where the church is any community gathering for worship and considering themselves to be a church.

Without excluding other contexts, the inner-city and township contexts of South Africa make such a broadening of particular importance. These contexts have in recent decades been marked by a particular fluidity of churches, with new churches constantly being started and repeatedly moving around as available spaces become too small or unavailable for various reasons (such as changes in rental agreements, interventions because of municipal bylaws, etc.). Fixed leadership structure (office), confessional and denominational traditions and permanent infrastructure simply do not define a large section of the church in this context.

Tradition and denominational affiliation, on the other hand, inevitably played an ongoing role in how we distinguished between churches, and how churches identified themselves. Churches are distinguished by noting how they describe their own identity. This often implies denominational affiliation, or affiliation with broad theological streams ('charismatic', 'Pentecostal' or 'evangelical'). However, the limitations of our current ecclesiological language to describe the South African urban ecclesial landscape became increasingly clear as we proceeded with the project. The broad descriptors of 'mainline' and 'charismatic', or even of particular denomination identities, do not adequately predict the particular ways in which churches organise themselves and think about their own identity and mission. This too is something which requires further research, so that our picture of the South African ecclesial landscape would speak to our own context, rather than repeatedly and exclusively importing ecclesial distinctions and then attempting to fit local churches onto these denominational maps. 
Looking back, we realise that our emphasis on public worship resulted in excluding communities of individuals gathered around a shared faith in a private manner. These might include forms of house churches or other gatherings which do not have a public gathering, even while they might gather for worship and actively respond to the social changes happening around them. This potentially includes migrant churches withdrawing into private spaces because of concerns over xenophobic violence. Furthermore, where worship does not include a fixed physical structure (as is the case with some African Independent Churches (AICs) worshipping around the city), we failed to adequately find and map these. In spite of our conceptual commitment, our research capacity and mapping methodologies were not always able to find all instances of what we would want to include in speaking about the church.

In brief, when we speak about the church throughout this research, it refers to the local worshipping community, noted as just one expression of church, but chosen as the expression which our research is focused on.

\section{Church and social change}

One of the things that our definition of church does is to refuse a predetermined church-sect distinction, with its almost inevitably evaluative implications, in describing the different ways in which churches interacts with society. The markers that are typically associated with sects in such a church-sect typology (cf. (Johnstone 2004:87, 92-95) can easily be noted in many of the smaller independent churches in Pretoria Central and Mamelodi East (e.g. small, with lay leadership, an emphasis on doctrinal purity and drawing primarily from the lower social classes of society), yet it was exactly such a close relationship to vulnerable people caught inside the urban fractures that drew us towards listening to the innovative responses to the changes in the urban landscape that emerge from these communities, not in spite of, but exactly because they are in many ways at the margins of society, worshipping and forming community from within the urban fractures and vulnerabilities which we were concerned with.

While our concern is not with an analysis of theories of social change, we understand social change to include the broad spectrum of political, economic, cultural and religious changes within a society over time. Of particular concern within this project was demographic change within the urban context, given the immense changes to the urban landscape after the end of apartheid in South Africa. Some of these changes will be addressed in specific articles emerging from the research, but this included changing demographics because of internal and cross-border migration and the changing racial demographic of the inner city.

It has become something of a truism that church and theology always exist and develop within particular contexts, and that changes in society inevitably result in changes in churches. Botha (2010) has described this as contextuality, to be distinguished from contextualisation, which implies a conscious taking into account of the social context in theological reflection and the activities of the church.

However, even where such a conscious taking into account of the social context and social changes is apparent (Botha's contextualisation), there is no uniform approach to how church and theology develop in context. As the classic typology of Bevans (2002) indicates, this ranges from a generally positive stance towards the context, allowing the changing social context to contribute to the construction of changes in church and theology, on the one hand, to a negative rejection of context, setting up the church in opposition to the social context, on the other hand. Simultaneously, this includes conscious attempts at transforming the social context, but also a conscious withdrawal and formation into a countercultural community. In spite of its diversity, all of these approaches can indeed honestly seek the welfare of the city and its people.

When reflecting on church responses to social change, it was therefore important to remain aware of both conscious responses to social change, as well as the ways in which churches were informed by changes in the social context without their conscious knowledge thereof.

Another relation between church and urban context, which we have not been able to explore adequately, but which we need to keep in mind, is that church and theology also inform the social context at times. For example, how does the appearance of multiple storefront and independent churches in urban areas, as well as the existence of older cathedrals in the inner city, over time also form the social context and social change of the city? Churches do not merely respond to the social context, but their very existence becomes part of the social context of the city.

Our assumption is therefore that churches are intimately tied to their social context, that they are formed by this context, respond to its changes, and that their very existence forms part of the social context of the city. From this, we developed various processes for listening to what local congregations are actually doing in response to what is happening in the city.

\section{Power and urban fractures}

The idea of urban fractures was central to our research questions (De Beer et. al. 2017). Key to our understanding of this notion is that fractures do not refer to any and all aspects of a heterogeneous community. Not every aspect of difference should be considered a fracture, much less a particularly urban fracture. Our critical evaluation of fractures is therefore not part of an attempt at creating a homogeneous city - on the contrary, the search for homogeneity is often the very source of fractures in general and urban fractures in particular.

Our initial committed position is important here, as descriptions of fractures require a certain moral and political 
analysis. Fractures are therefore not a morally neutral notion, but reveal the particular commitments of those doing the description. In our case, what we are concerned with is how urban fractures are tied with unequal power distributions which result in vulnerabilities which may be described as oppressions (De Beer 2015:3). The fractures become visible in the tension between inner city and suburb, or suburb and township, as inequality in access to social, economic or political power and resources result in particular vulnerable (see the 'Urban vulnerability' section) people living in the inner city and townships of Tshwane. Understanding how churches and their members are situated within this network of power relations, and how they respond creatively to these fractures, is the main purpose of this project.

Before further commenting on our use of fractures, the particular focus on urban fractures requires some attention. By emphasising urban fractures, we acknowledge that there are fractures that are not particularly urban. This should not be reduced to a simple matter of geography, where urban fractures refer merely to that which is found within a spatially demarcated area defined as urban. Indeed, we have to allow for the possibility of fractures impacting on people living in cities but which is not related to the urban context in which they are found at all. The focus on urban fractures is therefore an attempt to describe the fractures that are not only found within the city but also inherently tied to being within the city, to the way the city is structured and the manner in which it functions, to the effect of people living in closer proximity, of people gathering in this particular space because of the possibilities (or dreams) which urban contexts create, or because of the disruption of rural communities forcing people to look for economic livelihood.

Urban fractures are not necessarily universal either. Cities are extremely diverse, and while the concentration of people in the modern city inevitably also implies a concentration of power, fractures need to be described in its local particularity. In South Africa, in general, and Tshwane, in particular, the legacy of apartheid in determining racial residential patterns, is still part of this, ${ }^{7}$ and for the inner city of Pretoria, this includes the racial and economic contestations of white people and capital flight from the inner city, and more recent investment and development that threaten vulnerable parts of the inner city.

In particular, urban fractures are not merely found within a particular community, but in the inequalities - in terms of income, infrastructure, private and public spending, access to political and economic power and so on - between different parts of the city. The inner city and the township are then two very different contexts, with different fractures becoming visible as we look more closely.

Drawing on soteriological language, North American urban theologian Jim Perkinson (2004) captures these fractures in a way that goes to the heart of the urban tension:

7.See the so-called 'dot map' of Adrian Frith that uses Census 2011 data to visually display racial, linguisting and income distribution in the country - https://dotmap. adrianfrith.com/ what if salvation actually is all about salvation, that is to say, that there indeed is no wholeness at any level without wholeness at every level? What if, in fact, we are interlinked in such a way that the first world cannot become healthy without the two-thirds world also becoming healthy? Not as a matter of prescription, but as simple description? What if the suburb cannot quiet its angst without the city finding answer to its anger? (p. 514)

This wholeness, rather than homogeneity, is the opposite of fractures. For individuals and faith communities, it is quite often a search for wholeness within a particular community, but 'as a matter of prescription', this requires a search wholeness within the entire urban context, and taking note of how fractures and vulnerabilities in a particular community is always tied to the structures of the city more broadly (and beyond the city to how it is embedded within broader national and global context).

\section{Urban vulnerability}

Vulnerability is a concept that has particular currency within ecology, and drawing on the use of this notion in other fields assists in providing a lens for how we understand urban vulnerability. A striking example as far as this is concerned is addressing the consequences of changes in the structure and function of the biosphere. In a research project entitled $A$ framework for vulnerability analysis in sustainability science, the authors argue that vulnerability does not only derive from exposure to hazards, but resides in the sensitivity and resilience of the system experiencing such hazards (Turner et al. 2003). In our own reflection on the urban environment and peoples' interaction with changes within this environment, we attempt to remain sensitive to what the authors of the study call 'coupled human-environment systems' both in the inner city of Pretoria and Mamelodi East. The question we try to keep central is who and what are vulnerable to the multiple changes underway and where?

Connected to the type of vulnerability emerging from the coupled human-environment systems is the reality of social vulnerability. In The Concept of Social Vulnerability: A Review from Disasters Perspectives, Singh, Eghdami and Singh (2014) see vulnerability as 'made up of the characteristics of a person or group and their situation that influence their capacity to anticipate, to cope with, resist and recover from the impact of a natural hazard'. They go on to identify the factors causing or feeding into social vulnerability: physical, social, economic and environmental factors or processes, poverty, occupation, caste, ethnicity, exclusion, marginalisation and inequities in material consumption of a society or community.

These examples remind us that human vulnerability should not be disconnected from people's living environment. Both in the Central Business District of Pretoria and Mamelodi East, issues of poverty, disease, substance abuse and homelessness are not to be divorced from ecology and the broader urban geography. The point is illustrated by the formulation of one of the survey questions, ${ }^{8}$ namely, 'What 8.The survey is discussed in detail in De Beer et al. (2017). 
are the main challenges of your surrounding community'? The question itself suggests that those participating in the survey would turn their gaze to the 'surrounding community' in terms of the humans living and working there, the built environment and urban infrastructure, and also the ecology in its entirety.

When speaking about vulnerability, we therefore do not merely equate this with poverty. 'Although poor people are usually among the most vulnerable, not all vulnerable people are poor', rather vulnerability should be understood as:

insecurity and sensitivity in the well-being of individuals, households and communities in the face of a changing environment, and implicit in this, their responsiveness and resilience to risks that they face during such negative changes. (Moser 1998:3)

What we are ultimately concerned with the interaction between an individual and the immediate and broader environment around them. In urban areas, this concerns housing conditions and the effect of insecure lease agreements, changes to zoning or property values, or lack of adequate service delivery have in both the access to as well as the stability of living environments. We note vulnerability where people have no control over changes, and little resources for responding to these changes when they occur.

\section{Innovation}

'Innovation' has become something of a word of our times, often associated with technology, capitalism and entrepreneurship. For many, this is a neutral word, or even an inherent good, for a long time seldom considered as a potential object of moral reflection in itself (Russel \& Vinsel 2016). It should come as no surprise that the search for the 'innovative church' should often also start with a reflection on the church creatively to embrace technology and business practices around excellence (see, e.g., Isaac 2014).

The search for innovation and innovative practices among local congregations in the inner city of Pretoria and Mamelodi East was first and foremost a search for innovative responses to urban fractures and vulnerabilities. It is not a search for how the local congregations internalise the innovation of the market - for example, through effective use of digital technology in worship - but rather founded in the assumption that the local congregation in vulnerable communities could reveal innovative ways in which those poor and vulnerable respond to the challenged in their own contexts, as opposed to the solutions brought into these contexts by the representatives of the mission of the dominant church or the big developmental agencies.

Furthermore, in keeping with the framework expressed above, our main question was what a local faith community considers as an innovative activity. We do not distinguish between generative and adoptive innovations (Gopalakrishnan \& Damanpour 1997:17), accepting that a local faith community might consider something as innovative which have precedents elsewhere, yet still assist them in introducing responses to the fractured society in which they find themselves which is not the norm within the community or their tradition.

Our questions around innovation are therefore embedded within the broader theological commitments of the project, allowing for the agency of people in particular communities to analyse their own context and present proposals for how they would respond to the challenges they see around them. Drawing on the earlier argument on liberation theologies and our understanding of church, we therefore through this research want to question prevailing notions that 'innovation' in church and church relation to society comes from the churches connected to the technological and economical elite, and hope to start unearthing how it is exactly the churches of the poor which show the way in church response to urban fractures and vulnerabilities.

\section{A conceptual framework}

While these concepts and questions entered the design of the research project at different points, as will become clear in further publications, they are clearly intertwined and present a broad conceptual framework which informed our approach to the project. Key to this is the belief in the agency of people, in particular the poor, oppressed and vulnerable, to work creatively for their own liberation and for positive change in their own communities. In this case, 'the church' is not considered to be an outsider to these communities, but a key community which people from all walks of life, including those who are themselves vulnerable and exposed to the cracks of urban fractures, voluntarily join. It is our commitment to the agency of people who repeatedly brought us back to allowing local churches to articulate their own analysis of what the problems are that they consider to be facing their community, and also to share what they consider as possible ways that they could respond to this.

Brought together, this also highlights an understanding of people in the inner city of Pretoria and township of Mamelodi East as more than vulnerable. What we hoped to search for in the project is the ways in which those who are typically described as the recipients of aid bestowed upon them by various development organisations and NGOs, or in the context of this project by FBOs and rich, mostly suburban, churches, creatively and innovatively respond not only to the symptoms of urban fractures, but potentially also to the fractures themselves. Our starting point is that a commitment to liberation should include a commitment to taking the initiatives emerging from these faith communities seriously.

We hoped to turn the gaze away from the churches situated in places typically associated with 'innovation' in the contemporary technological and entrepreneurial environment, seeking for innovative responses to the 
fractures of the capital of South Africa among those left vulnerable in the face of these fractures. At times this also meant placing a hold on the analysis and proposals which our own theology of liberation lenses revealed, to allow participants in the various phases of the research project to articulate their own responses.

\section{Conclusion}

This article sheds light on the conceptual considerations that went into the design of the research project studying churches' engagement with urban fractures and vulnerabilities. One of the valuable things of working in a larger research group is exactly the way in which it forced us to more consciously reflect on concepts often glibly used in discussions on the church and its response to urban changes. Finding such conceptual clarity proved to be a key aspect of our joint research, and this article therefore underpins much of the further research outputs on particular questions that the project focused on, and also hopes to clear the way for ongoing research in urban theology, or more specifically, studies of church responses to urban social change. Given the key role of churches in the African context and the ongoing importance of urbanisation in shaping the African social landscape, such conscious reflection on the concepts drawn on in theological and social research on the role of churches is of particular importance.

\section{Acknowledgements Competing interests}

The author declares that he has no financial or personal relationships which may have inappropriately influenced him in writing this article.

\section{References}

Bazzell, P.D., 2015, Urban ecclesiology. Gospel of Mark, Familia Dei and a Filipino community facing homelessness, Bloomsbury T\&T Clark, London.

Bevans, S.B., 2002, Models of contextual theology, Orbis Books, New York.

Bosch, D.J., 2004, Transforming mission, Orbis, New York.

Botha, N., 2010, 'If everything is contextual, nothing is contextualisation: Historical methodological and epistemological perspectives', Missionalia 38(2), 181-196.

De Beer, S.F., 2015, 'Reading psalms, and other urban poems, in a fractured city', Verbum et Ecclesia 36(1), 1-8. https://doi.org/10.4102/ve.v36i1.1472

De Beer, S.F., Smith, R.D., \& Manyaka, J., 2017, 'Trans-disciplinary research on religious formations in urban Africa: Toward liberative methodological approaches', HTS Teologiese Studies/Theological Studies 73(3), Art. \#4693 ...?

Freire, P., 1996, Pedagogy of the oppressed. London: Penguin Books.

Gopalakrishnan, S. \& Damanpour, F., 1997, 'A review of innovation research in economics, sociology and technology management', Omega: International Journal of Management Science 25(1), 15-28.

Hankela, E., 2014, 'Faith community as a centre of liberationist praxis in the city', HTS Teologiese Studies/Theological Studies 70(3), 1-9. https://doi.org/10.4102/hts. vioi3.2768
v70iese

Isaac, P., 2014, The innovative church of the 21st century, iUniverse, Bloomington, IN.

Johnstone, R.L., 2004, Religion in society: A sociology of religion, 7th edn., Pearson, Upper Saddle River, NJ.

Moser, C.O., 1998, 'The asset vulnerability frameword: Reassessing urban poverty reduction strategies', World Development 26(1), 1-19. https://doi.org/10.1016/ S0305-750X(97)10015-8

Perkinson, J.W., 2004, 'Like a thief in the night: Black theology and white church in the Third Millennium', Theology Today 60, 508-524. https://doi.org/10.1177/ 004057360406000405

Russel, A. \& Vinsel, L., 2016, Hail the maintainers, Aeon, viewed 10 April 2016, from https://aeon.co/essays/innovation-is-overvalued-maintenance-often-matters-more

Singh, S.R., Eghdami, M.R., \& Singh, S., 2014, 'The concept of social vulnerability: A review from disasters perspectives', Journal of Interdisciplinary and Multidisciplinary Studies 1(6), 71-82.

Smit, D.J., 2008, Geloof en die openbare lewe, Sun Press, Stellenbosch.

Tshaka, R.S., 2010, 'Do our theological methodologies help us to deal with situations of violence in black communities?', Journal of Theology for Southern Africa 138, 124-135.

Turner, B.L., Kasperson, R.E., Matsone, P.A., McCarthyf, J.J., Corellg, R.W., Christensen, L. et al., 2003, 'A framework for vulnerability analysis in sustainability science', Proceedings of the National Academy of Sciences of the United States of America 100, 8074-8079. https://doi.org/10.1073/pnas.1231335100

Vellem, V., 2012, 'Interlocution and black theology of liberation in the 21st century: A reflection', Studia Historiae Ecclesiasticae 38, 345-360.

Volf, M., 1998, After our likeness: The church as the image of the trinity, William B. Eerdmans, Grand Rapids, MI. 